\title{
Correlation and Path Analysis in Pigeonpea [Cajanus cajan (L.) Millsp.]
}

\author{
L. M. Tharageshwari and A. Thanga Hemavathy* \\ Department of Pulses, Centre for Plant Breeding and Genetics, Tamil Nadu Agricultural \\ University, Coimbatore - 641 003, India \\ *Corresponding author
}

Keywords

Pigeonpea,

Correlation, path analysis, selection)

Article Info

Accepted:

15 December 2019

Available Online:

20 January 2020
Correlation between yield and yield attribute component traits in ninety three genotypes of pigeon pea revealed that single plant yield had positive and highly significant association with pod weight per plant, number of pods per plant and shelling percentage. The selection criteria can be done based on these characters for seed yield will give successful results for yield improvement in pigeon pea. Path coefficient analysis of different traits on single plant yield recorded that traits viz., pod weight per plant, number of pods per plant and shelling percentage showed highest positive direct effect. Hence selection on these studied characters might be useful in Pigeon pea yield improvement.

\section{Introduction}

Pigeon pea is the second most important protein rich pulse crop after chickpea in India and fifth most important crop in the world. Pigeon pea or red gram (Cajanus cajan) $2 n=2 x=22$ is globally covered and grown in India. In India it occupies an area of about $5.39 \mathrm{~m}$ ha with an annual production of 4.60 million tonnes with the productivity of $913 \mathrm{~kg}$ /ha. (FAOSTAT (2018)). Pigeon pea is the main source of protein for Indian vegetarians and it contains $20-21 \%$ of proteins. Seeds are used as green peas, split peas and whole grain. The world health organization recommended that the per- capita consumption of protein around $80 \mathrm{~g} /$ day whereas the per-capita availability of protein in the country is about $28 \mathrm{~g} /$ day leads to malnutrition for the growing population.(Saroj et al., (2013)). To meet out the protein needs and to overcome from the biotic and abiotic stresses, genetically stable genotypes having high yield potential are mandatory.

Yield is a complex character which is controlled by polygenes. For enhancing the yield, better understanding of contributing character is essential and keeping this view the present study was carried out to find the inter- 
relationship among the yield and its contributing traits and also their direct and indirect effect contribution to yield.

\section{Materials and Methods}

The present experiment comprised of ninety three genotypes of Pigeon pea obtained from the Department of pulses, TNAU, Coimbatore during the year 2018-19. The experiment was conducted by Augmented Completely Randomized Design I. Four checks were replicated four times randomized, throughout the experimental area irrespective of blocks. The observations were recorded on five competitive randomly selected plants in each plot for the traits viz., plant height, number of branches per plant, number of pods per plant, pod length, number of seeds per pod, 100 seed weight, grain yield per plant, days to 50\% flowering and days to maturity.

The phenotypic correlation coefficients were computed using the formula suggested by Falconer (1964). The Path-coefficient analysis was conducted as described by Dewey and Lu (1959). Data obtained were subjected to correlation and path co-efficient analysis using statistical software TNAUSTAT statistical package (Natarajan and Manivannan, 2014).

\section{Results and Discussion}

Correlation between single plant yield and other traits were presented in the Table 1 for ninety three germplasm at phenotypic level. Single plant yield had positive and highly significant association with pod weight per plant (0.727), number of pods per plant (0.947) and shelling percentage (0.446). Negative and highly significant relationship was noticed with plant height $(-0.342)$ and pod bearing length (-0.331). Number of primary branches per plant (0.039), raceme number $(0.186)$, number of seeds per pod (0.130) and hundred seed weight (0.091) had positive but non-significant association with single plant yield. Whereas days to fifty per cent flowering $(-0.050)$ and days to maturity (-0.171) exhibited negative and non-significant association with single plant yield. The single plant yield had highly significant and positive association with pod weight per plant, number of pods per plant and shelling percentage.

Pushpavalli et al., (2017), Pal et al., (2018) and Prasad et al., (2013) reported the similar results for the trait number of pods per plant. Sarsamkar et al., (2008), Thanki and Sawargaonkar (2010) and Narayanan et al., (2018) corroborated similar findings. Linge $e t$ al., (2010), Kumara et al., (2014), Nethravathi and Patil (2014), Vanisree and Sreedhar (2014) also reported similar results. Similar research proof were given by Kesh et al., (2017) and Pal et al., (2018) for the trait number of seeds per pod. The significant and negative association was noticed for single plant yield through plant height and pod bearing length. Similar research outcome was reported by Chandirakala and Subbaraman (2010) for plant height. Prasad et al., (2013) reported for pod bearing length. Days to fifty per cent flowering showed highly significant and positive correlation with days to maturity, while positive and significant association with number of primary branches per plant and raceme number.

The same results were corroborated by Vanisree and Sreedhar (2014), Sodavadiya et al., (2009) and Mahajan et al., (2007) for number of branches per plant and Chandana $e t$ al., (2014), Vanisree and Sreedhar (2014), Kumara et al., (2014), Linge et al., (2010) for days to maturity. Narayanan et al., (2018) and Pal et al., (2018) reported the similar research outcome for number of pods per plant. Days to maturity exhibited positive and significant correlation with number of primary branches per plant and raceme number. 
Table.1 Correlation coefficient between thirteen quantitative characters in pigeon pea germplasm

\begin{tabular}{|c|c|c|c|c|c|c|c|c|c|c|c|c|c|}
\hline & DFF & PH & DM & NPB & $\mathbf{R N}$ & PBL & PL & PWPP & NSPP & NPPP & HSW & SP & SPY \\
\hline DFF & 1 & -0.098 & $0.860^{* *}$ & $0.210^{*}$ & $0.207^{*}$ & -0.082 & -0.006 & 0.067 & -0.086 & -0.156 & -0.018 & -0.107 & -0.050 \\
\hline PH & & 1 & 0.008 & 0.076 & -0.044 & $0.939^{* *}$ & 0.072 & -0.202 & -0.155 & $-0.349^{* *}$ & -0.087 & $-0.294^{* *}$ & $-0.342^{* *}$ \\
\hline DM & & & 1 & $0.256^{*}$ & $0.209^{*}$ & 0.033 & -0.036 & 0.022 & -0.008 & $-0.264^{*}$ & -0.099 & $-0.226^{*}$ & -0.171 \\
\hline NPB & & & & 1 & $0.685^{* *}$ & -0.018 & -0.173 & 0.140 & -0.092 & -0.073 & -0.137 & -0.043 & 0.039 \\
\hline $\mathbf{R N}$ & & & & & 1 & -0.079 & -0.164 & $0.284^{* *}$ & -0.057 & 0.101 & 0.063 & -0.003 & 0.186 \\
\hline PBL & & & & & & 1 & 0.143 & -0.190 & -0.131 & $-0.327^{* *}$ & -0.053 & $-0.281^{\text {** }}$ & $-0.331^{* * *}$ \\
\hline PL & & & & & & & 1 & -0.031 & -0.024 & -0.132 & 0.044 & -0.143 & -0.130 \\
\hline PWPP & & & & & & & & 1 & 0.115 & $0.669^{* *}$ & 0.041 & $-0.228^{*}$ & $0.727^{* *}$ \\
\hline NSPP & & & & & & & & & 1 & 0.186 & 0.148 & -0.011 & 0.130 \\
\hline NPPP & & & & & & & & & & 1 & .111 & $0.434^{* *}$ & $0.947^{* *}$ \\
\hline HSW & & & & & & & & & & & 1 & 0.070 & 0.091 \\
\hline SP & & & & & & & & & & & & 1 & $.446^{* *}$ \\
\hline SPY & & & & & & & & & & & & & 1 \\
\hline
\end{tabular}

*Significant at $5 \%$ level $\quad * *$ Significant at $1 \%$ level

\begin{tabular}{|c|c|c|c|c|c|}
\hline DFF & Days to fifty per Cent flowering & PBL & Pod bearing length (cm) & HSW & Hundred Seed weight (g) \\
\hline PH & Plant height (cm) & PL & Pod length $(\mathrm{cm})$ & SP & Shelling percentage \\
\hline DM & Days to maturity & PWPP & Pod weight / plant (g) & SPY & Single Plant yield (g) \\
\hline $\mathbf{R N}$ & Raceme number & NPPP & Number of pods / plant & & \\
\hline
\end{tabular}


Table.2 Direct (Diagonal) and indirect effects of thirteen character on single plant yield in pigeon pea

\begin{tabular}{|c|c|c|c|c|c|c|c|c|c|c|c|c|c|}
\hline Characters & DFF & PH & DM & NPBPP & RN & PBL & PL & PWPP & NSPP & NPPP & HSW & SP & SPY \\
\hline DFF & 0.0378 & -0.0095 & -0.0056 & 0.0045 & -0.0058 & 0.0054 & 0.0001 & 0.0349 & 0.0001 & -0.0711 & 0.0001 & -0.0404 & -0.0498 \\
\hline $\mathbf{P H}$ & -0.0037 & 0.0969 & -0.0001 & 0.0016 & 0.0012 & -0.0623 & 0.0001 & -0.1047 & 0.0001 & -0.1597 & -0.0002 & -0.1115 & -0.3422 \\
\hline DM & 0.0325 & 0.0008 & -0.0065 & 0.0055 & -0.0058 & -0.0022 & -0.0001 & 0.0112 & 0.0011 & -0.1205 & -0.0002 & -0.0857 & -0.1709 \\
\hline NPBPP & 0.0079 & 0.0074 & -0.0017 & 0.0215 & -0.0191 & 0.0012 & -0.0003 & 0.0725 & 0.0001 & -0.0335 & -0.0003 & -0.0165 & 0.0391 \\
\hline $\mathbf{R N}$ & 0.0078 & -0.0043 & -0.0014 & 0.0147 & -0.0279 & 0.0053 & -0.0003 & 0.1467 & 0.0126 & 0.0464 & 0.0001 & -0.0011 & 0.1861 \\
\hline PBL & -0.0031 & 0.0909 & -0.0002 & -0.0004 & 0.0022 & -0.0664 & 0.0003 & -0.0983 & 0.0001 & -0.1494 & -0.0001 & -0.1065 & -0.3309 \\
\hline PL & -0.0002 & 0.007 & 0.0002 & -0.0037 & 0.0046 & -0.0095 & 0.002 & -0.0158 & 0.0470 & -0.0604 & 0.0001 & -0.0544 & -0.1302 \\
\hline PWPP & 0.0025 & -0.0196 & -0.0001 & 0.003 & -0.0079 & 0.0126 & -0.0001 & 0.5174 & -0.0001 & 0.3059 & 0.0001 & -0.0866 & 0.7272 \\
\hline NSPP & -0.0033 & -0.015 & 0.0001 & -0.002 & 0.0016 & 0.0087 & 0.0001 & 0.0592 & -0.0008 & 0.0851 & 0.0003 & -0.0041 & 0.1299 \\
\hline NPPP & -0.0059 & -0.0338 & 0.0017 & -0.0016 & -0.0028 & 0.0217 & -0.0003 & 0.3463 & -0.0001 & 0.4571 & 0.0002 & 0.1646 & 0.9471 \\
\hline HSW & -0.0007 & -0.0084 & 0.0006 & -0.0029 & -0.0018 & 0.0035 & 0.0001 & 0.0212 & -0.0001 & 0.0509 & 0.002 & 0.0266 & 0.0911 \\
\hline SP & -0.004 & -0.0285 & 0.0015 & -0.0009 & 0.0001 & 0.0186 & -0.0003 & -0.1181 & 0.0001 & 0.1983 & 0.0001 & 0.3794 & 0.4462 \\
\hline
\end{tabular}

Residual effect $=\mathbf{0 . 1 9 5 0}$

\begin{tabular}{|c|c|c|c|c|c|}
\hline DFF & Days to fifty per Cent flowering & PBL & Pod bearing length (cm) & HSW & Hundred Seed weight (g) \\
\hline PH & Plant height (cm) & PL & Pod length $(\mathrm{cm})$ & & Shelling percentage \\
\hline DM & Days to maturity & PWPP & Pod weight / plant (g) & SPY & Single Plant yield (g) \\
\hline NPBPP & Number of primary branches / Plant & NSPP & Number of seeds / pod & & \\
\hline RN & Raceme number & NPPP & Number of pods / plant & & \\
\hline
\end{tabular}


The results are in harmony with Vanisree and Sreedhar (2014), Mahajan et al., (2007), Sodavadiya et al., (2009) and Verma (2018) for number of branches per plant. Number of pods per plant had positive and highly significant correlation with single plant yield. This was supported by Vanisree and Sreedhar (2014). Raceme number expressed positive and highly significant association with pod weight per plant similar result was reported by Pandey et al., (2016). Based on the correlation studies number of pods per plant, pod weight per plant and shelling percentage showed highly positive association with single plant yield. Hence these traits could be included while designing the selection index in yield enhancing breeding programme.

Path coefficient analysis was done to determine the direct and indirect contributions of different traits towards single plant yield. The results were presented in Table 2 . Residual effect was found to be 0.195 , which indicated that the characters under study were contributed to $80.50 \%$ of total variation. Hence, selection on these studied characters might be useful in genetic improvement for yield. The direct effect of different traits on single plant yield revealed that the traits, pod weight per plant (0.5174), number of pods per plant (0.4571) and shelling percentage (0.3794) showed highest positive direct effect. Days to fifty per cent flowering (0.0378), plant height (0.0969), number of primary branches per plant (0.0215), pod length (0.002) and hundred seed weight (0.002) had negligible and positive direct effects on single plant yield. Negative and negligible direct effect on single plant yield was observed by the traits viz., days to maturity $(-0.0065)$, raceme number (-0.0279), pod bearing length $(-0.0664)$ and number of seeds per pod (0.0008) (Table 2). The high and positive direct effect on single plant yield was exhibited by the traits, viz., pod weight per plant, number of pods per plant and shelling percentage.
Similar research proofs were reported by Vange and Egbe (2009) and Niranjana Kumara et al., (2014). Considerable effect of shelling percentage on single plant yield was reported by Pandey et al., (2016). Verma (2018) reported that number of pods per plant had positive direct effect on single plant yield. Days to fifty per cent flowering, plant height, number of primary branches per plant, pod length and hundred seed weight had negligible and positive direct effects on single plant yield. High direct effect of number of branches per plant on single plant yield was reported by Prasad et al., (2013), Kesh et al., (2017) and Pandey et al., (2016). Negative and negligible direct effect on single plant yield was observed by the traits viz., day to maturity, raceme number, pod bearing length and number of seeds per pod. Krishna Chaithanya et al., (2014) and Pandey et al., (2016)corroborated similar results. Singh et al., (2013) reported similar research proof for days to maturity and plant height. The high indirect effect on single plant yield was imposed by number of pods per plant, pod weight per plant. Similar results were reported by, Nethravathi and Patil (2014), Pushpavalli et al., (2017), Pal et al., (2018) and Narayanan et al., (2018).

Based on the correlation studies number of pods per plant, pod weight per plant and shelling percentage showed highly positive association with single plant yield. Hence these traits could be included while designing the selection index in yield enhancing breeding programme. Path coefficient analysis, the residual effect of path coefficient analysis was 0.1950 which is indicating the sufficiency of number of traits under consideration for crop improvement. It was inferred that the traits viz., number of pods per plant, pod weight per directly contribute to single plant yield. Therefore, they can be considered in a breeding programme for improvement of single plant yield. 


\section{References}

Chandana, K., L. Prasanthi, M. R. Sekhar, and B. Reddy. 2014. "Studies on correlation and path analysis for yield and its attributes in rabi redgram." Indian Journal of Agricultural Research 48 (1):47-51.

Chandirakala, R., and N. Subbaraman. 2010. "Character association and path analysis for yield attributes in full sib progenies in Pigeonpea (Cajanus cajan (L.) Mill Sp.)." Electronic Journal of Plant Breeding 1 (4):824-827.

Falconer, D. S. 1964. An Introduction to Quantitative Genetics: Oliver and Boyd Ltd., Edinburgh.

Dewey, Douglas R, and Lu KH. 1959. "A Correlation and Path-Coefficient Analysis of Components of Crested Wheatgrass Seed Production 1." Agronomy Journal 51 (9):515-518.

Kesh, H., A. Yadav, A. Sarial, S. Khajuria, and B. Jain. 2017. "Genotypic Variability and Character Association among Yield and Yield Contributing Traits in Pigeonpea (Cajanus cajan L. Millsp)." Research Journal of Agricultural Sciences 8 (1):194-198.

Krishna Chaithanya, B., L. Prasanthi, K. H. Reddy, and B. Bhaskara Reddy. 2014. "Association and path analysis in $\mathrm{f} 2$ populations of Pigeonpea [Cajanus cajan (1.) millsp]." Legume Research: An International Journal 37 (6):561567

Kumara, NB, PS Dharmaraj, and VB Wali. 2014. "Genetic diversity and variability studies of advance breeding lines of Pigeonpea (Cajanus cajan. L). International Journal adv. Pharm. Bio. Chem 3 (2):404-409

Linge, S., H. Kalpande, S. Sawargaonkar, B. Hudge, and H. Thanki. 2010. "Study of genetic variability and correlation in interspecific derivatives of Pigeonpea
[Cajanus cajan (L.) Millsp.]." Electronic Journal of Plant Breeding 1 (4):929-935.

Mahajan, V, SK Shukla, V Tiwari, SVS Prasad, and HS Gupta. 2007. "Path Analysis in Pigeonpea (Cajanus cajan (L.) Millsp.) in Mid-altitudes of Northwestern Himalyas." Crop Improvement India 34 (1):56.

Nethravathi, KH, and BR Patil. 2014. "Character association and path coefficient analysis for yield and its components in pigeonpea." Karnataka Journal of Agricultural Sciences 27 (2):225-226.

Narayanan, S. L., N. Manivannan, and A. Mahalingam. 2018. "Correlation and Path Analyses of Yield and its Component Traits in Pigeonpea [Cajanus cajan (L.) Millsp.]." International Journal of Current Microbiology and Applied Science 7 (03):614-618.

Pal, D., S. Verma, R. Panwar, A. Arora, and A. K. Gaur. 2018. "Correlation and Path Analysis Studies in Advance Lines of Pigeonpea [Cajanus cajan (L.) Millspaugh] under Different Environments." International Journal of Current Microbiology and Applied Sciences 7 (4):378-389.

Prasad, Y., K. Kumar, and S. Mishra. 2013. "Studies on genetic parameters and interrelationships among yield and yield contributing traits in Pigeonpea [Cajanus cajan (L.) Millsp.]." The bioscan 8 (1):207-211.

Pushpavalli, S., C. Sudhakar, C. S. Rani, R. R. Rajeswari, and C. J. Rani. 2017. "Genetic divergence, correlation and path coefficient analysis for the yield components of pigeonpea genotypes. Legume Research 40 (3):439-443.

Pandey, Praveen, Kumar, and Pandey. 2016. "Genetic association studies for yield and yield related traits in Pigeonpea 
[Cajanus cajan (L.) Millsp.]." Legume Research 39 (2):189-193.

Saroj, S., M. Singh, R. Kumar, T. Singh, and M. Singh. 2013. "Genetic variability, correlation and path analysis for yield attributes in pigeonpea." The bioscan 8 (3):941-944.

Sarsamkar, S., S. Borgaonkar, S. Kalyankar, B. Kadam, and G. Kadam. 2008. "Genetic variability studies in pigeon pea (Cajanus cajan (L.) Millsp.)." International Journal of Plant Science 3 (2):502-503.

Sodavadiya, P., M. Pithia, J. Savaliya, A. Pansuriya, and V. Korat. 2009. "Studies on characters association and path analysis for seed yield and its components in pigeonpea (Cajanus cajan (L.) Millsp)." Legume Research 32 (3):203-205.

Singh, J., R. A. Fiyaz, S. Kumar, M. Ansari, and S. Gupta. 2013. "Genetic variability, correlation and path coefficient analysis for yield and its attributing traits in pigeonpea (Cajanus cajan) grown under rainfed conditions of Manipur." Indian Journal of Agricultural Sciences 83 (8):852-858.

Vanisree, S., and M. Sreedhar. 2014. "Genetic analysis of yield and yield components and determination of selection criteria in pigeonpea germplasm." Journal of food legumes 27 (1):68-70.

Verma, S. K., Bisht, C., Gaur, A. K., \& Chandra, D. 2018. "Study on some genetic parameters for yield and related traits in pigeonpea [Cajanus cajan (L.) Millspaugh] genotypes.." Chem Sci Rev Lett 7 (25):70-76.

Vange, T., and M. Egbe. 2009. "Studies on genetic characteristics of pigeon pea germplasm at Otobi, Benue State of Nigeria. World Journal of Agricultural Sciences 5 (6):714-719.

Thanki, H., and S. Sawargaonkar. 2010. "Path coefficient analysis in pigeonpea (Cajanus cajan L. Millsp.)." Electronic Journal of Plant Breeding 1 (4):936939.

\section{How to cite this article:}

Tharageshwari, L. M. and Thanga Hemavathy, A. 2020. Correlation and Path Analysis in Pigeonpea [Cajanus cajan (L.) Millsp.]. Int.J.Curr.Microbiol.App.Sci. 9(01): 80-86. doi: https://doi.org/10.20546/ijcmas.2020.901.009 